\title{
Correlation Between Reading Fondness and Attitude Toward Science at Middle School
}

\author{
Tanti $^{1 *}$, Dwi Agus Kurniawan ${ }^{2}$, Riko Firmansyah ${ }^{3}$, Muhammad Sofyan Zain ${ }^{4}$ \\ ${ }^{1}$ Physics, UIN Sulthan Thaha Saifuddin, Jambi, Indonesia \\ 2,3,4,5 Physics Education, Jambi University, Jambi, Indonesia \\ e-mail: tanti@uinjambi.ac.id ${ }^{1}$, dwiagus.k@unja.ac.id², firmansyahriko321@gmail.com³ \\ sofyanzain467@gmail.com ${ }^{4}$
}

\begin{abstract}
This research was conducted to analyze the correlation between reading fondness and attitude toward science. The number of research samples was 145 students. The research method used is a mix of quantitative and qualitative instruments that are descriptive. Quantitative instrument data collection techniques in the form of questionnaires and observations, qualitative instruments in the form of documentation and interviews. The statistical results of the attitude toward science variable, the average student chooses neutral in all indicators. The reading fondness variable of indicators general attitude towards reading and students' reading preferences average students chose neutral, the effect of reading on the ability of students chose to agree, and negative views of students towards reading chose not to agree. Based on the significance of $0.048<0.05$. So it can be concluded that there is a weak correlation between the attitude and reading variables.
\end{abstract}

Keywords: Attitud, Reading, Science

\section{Introduction}

Education is one of the pillars of character building for students in school. Characterbased education is education that applies principles and methodologies towards the character building of students through an integrated curriculum developed in schools (Dewi, Budiarti, \& Aina, 2017). In the current curriculum in Indonesia, teachers are required to be professional in preparing learning materials, models, learning strategies, use of learning tools, innovative learning methods, and have a teaching style that can generate a pleasant and meaningful learning environment (Rumahlatu, Huliselan, \& Takaria, 2016). The current problem, some teachers still use conventional teaching methods, namely learning that only prioritizes the cognitive domain, learning activities that are too bound to cognitive will kill the character of students so students become not creative, not confident, depressed, even stressed, and do not love learning (Mayasari, Syamsurizal, \& Maison, 2015). Emphasis on the cognitive domain will override the affective domain and character of students. The negative character shown by students during learning is reflection of a negative attitude towards the subject, so that character and attitude are an inseparable unity. Student attitudes towards a subject are influenced by internal factors as one of them. According to Astalini, Maison, Ikhlas, \& Kurniawan (2018), internal factors are factors originating from within students, internal factors have two aspects namely physiological aspects (body, eyes, and ears) and psychological aspects (student intelligence, student attitude, talent students, student interests and student motivation). The character likes to read is one of the many characters' students must apply inside or outside the learning activities. Likes to read is a feeling of liking reading and makes reading a habit. Likes to read are characters that are needed in the world of education. Because the knowledge we have gained so far has come from literary sources in the form of writing. Negative or positive attitudes toward science subjects can be seen from the character of reading fondness that researchers want to know the correlation.

Improving the quality of education in Indonesia must start from the quality of its teaching staff (Asrial, Syahrial, Kurniawan, \& Septiasari, 2019). Beginning with understanding positive

\footnotetext{
${ }^{*}$ Corresponding author.

Received 25 May 2020; Accepted 09 September 2020; Available online 25 March 2021

(C) 2020 JPI. All Rights Reserved
}

Jurnal Pendidikan Indonesia (JPI) | 46 
attitudes and character and how to connect, the teacher will be able to bring changes in students specifically in science subjects. These attitudes and characters come from within you and are very related to feelings or psychological (Webber, 2015). Psychological aspects included in the affective domain are attitudes and can determine students like or dislike about a subject so that interest in learning can increase or not increase (Astalini, Kurniawan, \& Sumaryanti, 2018). According to Kurniawan, Astalini, \& Anggraini (2018), students' attitudes towards science subjects are good and some are not good, also called positive and negative attitudes. Students 'Attitudes towards Science Visit from students' responses to Science. If many students oppose science because it is difficult, it can make students oppose science because students do not like science. According to Dwianto, Wilujeng, Prasetyo, \& Suryadarma (2017), scientific attitudes are different from attitudes towards science. According to Astalini, Kurniawan, Melsayanti, \& Destianti (2018), scientific attitudes require students to be able to understand concepts, and conduct experiments in the field of science, so students are active then students' insights and motivations become better and students have positive attitudes towards science. Scientific attitude is an attitude in the realm of science, according to Silaban (2017), the attitude of science consists of goals, honest, unhurried, cautious, not confusing facts with judgment, caution, wanting to be changed, and curious. Scientific attitudes change the positive attitude towards science. According to (Piawi, Kalmar Nizar, \& Mawardi, 2018), scientific attitudes manifest as actions toward objects. Understanding the importance of attitudes towards science will bring changes in students, can be seen from the correlation with the character likes to read whether it is contradictory or not.

In learning activities, teachers are not only required to be able to channel knowledge, but also must be able to change the attitudes and character of students from negative to positive towards all the supporting tools for the implementation of education. This attitude and character become an important thing to be improved to increase learning enthusiasm. The attitude and character values need to be implemented in learning through structured plans. Teachers must also be able to plan learning by preparing lesson plans that contain the values of attitudes and character (Fatimah \& Usman, 2017). The use of lecture methods is still often found in class and negatively affects the attitudes and character of students. With the lecture method, the teacher cannot change the negative attitude towards science. To change attitudes, the use of lecture methods in natural science subjects should be avoided, because science subjects require scientific completion and use scientific methods (Syafitri, Asyhar, \& Asrial, 2016).

The development of science and technology is very influential in the development of education (Syahrial et al., 2019). The ability of teachers to teach now is expected to be able to keep abreast of the times which are full of information technology while enhancing students' abilities in all aspects. To improve students' abilities and attitudes on science subjects, teachers must use learning models that support creative thinking (Ernawati, Muhammad, Asrial, \& Muhaimin, 2019a). Improving the quality of education into a productive, creative, innovative, and effective generation through the integration of attitudes, abilities, and knowledge with life skills (Ernawati, Muhammad, Asrial, \& Muhaimin, 2019b). Also, the influence of the development of information technology also affects students' fondness for reading. Digital reading is now more often used than non-digital reading because there are unlimited sources of digital information. Reading is indeed a positive thing because it can provide knowledge to readers. In this case, the source of the reading is a determinant of the intensity of a student's knowledge, so it is very good if you have many sources of reading. Reading sources can be obtained from digital (digital magazines, electronic journals, electronic books, etc.) and conventional (textbooks, worksheets, etc.) both are distinguished by the ease in obtaining them. Of course in the ease of obtaining information, digital reading sources play a large role today, this was conveyed in the opinion of Supriyadi \& Kholid (2016), the existence of digital reading sources makes it possible to obtain information that is efficient, practical, and flexible. Besides reading digital and conventional information sources have differences that are based on aspects of ease of travel and do not require a large storage space (Nurchaili, 2016). Therefore, reading sources are not limited to conventional means, namely, digital sources are also included. 
Based on the explanation above, reading fondness and attitude towards science should be known how the condition is in the classroom and how the correlation between the two. Correlation is intended so that readers know whether they have a mutually reinforcing relationship, one strengthens and one weakens, or there is no relationship at all between the two. For teachers and schools, this research will help find out when students are increasingly encouraged to read, whether their attitude toward science is more positive or not.

\section{Method}

The location of this study was conducted at SMPN 19 Jambi City. This location was chosen because the location was more accessible and accessible to researchers and so far there has been no research on reading fondness towards attitudes in the school. The total sample of 145 students and students ranging from classes VII D, VII E, VII F, VII G, VII H, and $\mathrm{VIII} \mathrm{H}$. The research method that the researchers used was a mix of quantitative and qualitative instruments which were descriptive in nature. The quantitative instruments were in the form of questionnaires, while the qualitative instruments were in the form of interviews with 1 student, 1 student, and 1 natural science teacher. The advantage of quantitative methods is that they are systematic, planned, and structured from the beginning to the making of their research designs (Siyoto \& Sodik, 2015). In addition, researchers use quantitative methods as the main method, while the use of qualitative methods as a supporter of quantitative methods (Salim \& Haidir, 2019). According to (Creswell \& Creswell, 2018), qualitative research is carried out by researchers by identifying and explaining what is happening in the field and why it can happen. Data collection techniques that researchers do is by survey (field research) conducted by distributing questionnaires and interviews (Ruel, III, \& Gillespie, 2016). The data the researcher obtained was primary data that is taken directly from the research subject.

Data collection techniques that researchers do by using quantitative research instruments in the form of questionnaires and observations. There are 2 types of questionnaires that researchers give to students, among others, the attitude of science questionnaire adopted from the research by Astalini \& Kurniawan (2019), took 3 indicators namely career interest in the field of science, pleasure in learning science, interest in increasing the amount of science learning time with a number of statements of 23 items. Then the reading fondness questionnaire was adapted from the research by (Ahmed, 2016; Liswaniso \& Mubanga, 2019), with 4 indicators namely general attitudes towards reading, student reading preferences, the effect of reading on students' abilities and negative views of students towards reading with a total of 40 statements. Both questionnaires use a Likert scale of 5 items that is strongly disagree (STS) point 1, disagree (TS) point 2, neutral (N) point 3, agree (S) point 4, and strongly agree (SS) point 5 for positive statements, while strongly disagree (STS) point 5 , disagree (TS) points 4 , neutral $(\mathrm{N})$ point 3 , agree $(\mathrm{S})$ point 2 , and strongly agree (SS) point 1 for negative statements. Source of data collected directly by researchers which is primary data. While observations are made by documenting when students fill out a questionnaire. For qualitative data in the form of documentation and interviews using interview sheets for 2 students. Source of data collected directly by researchers which is primary data. While observations are made by documenting when students fill out a questionnaire. For qualitative data in the form of documentation and interviews using interview sheets for 2 students. Source of data collected directly by researchers which is primary data. While observations are made by documenting when students fill out a questionnaire. For qualitative data in the form of documentation and interviews using interview sheets for 2 students. The following table is the distribution of questionnaire statement of attitude towards natural science and the indicators.

Table 1. Distribution of Statements of Attitude Indicators

\begin{tabular}{lccc}
\hline Variable & Indicator & Num. Statement Items & $\begin{array}{c}\text { Number of } \\
\text { Items }\end{array}$ \\
\hline Attitude & $\begin{array}{c}\text { Career interests in the natural } \\
\text { sciences }\end{array}$ & $\begin{array}{c}7^{*}, 14,21^{*}, 28,35^{*}, \\
40.45^{*}, 49.52^{*}, 54^{*}\end{array}$ & 10
\end{tabular}




\begin{tabular}{|c|c|c|c|}
\hline Variable & Indicator & Num. Statement Items & $\begin{array}{l}\text { Number of } \\
\text { Items }\end{array}$ \\
\hline & Fun in learning science & $\begin{array}{c}5,12^{*}, 19,26{ }^{*}, 33,38^{*} \\
43.47^{*}, 51.53^{*}\end{array}$ & 10 \\
\hline & $\begin{array}{l}\text { Interest increases the amount of } \\
\text { time studied in science }\end{array}$ & $\begin{array}{c}6,13^{*}, 20,27^{*}, 34,39 * \\
44.48^{*}\end{array}$ & 8 \\
\hline & \multicolumn{2}{|c|}{ Item Total } & 23 \\
\hline
\end{tabular}

The next table is the distribution of questionnaire statement of Reading Fondness and the indicators.

Table 2. Distribution of statement of reading fondness indicators

\begin{tabular}{|c|c|c|c|}
\hline Variable & Indicators & Num. Statement Items & $\begin{array}{l}\text { Number of } \\
\text { Items }\end{array}$ \\
\hline \multirow{5}{*}{$\begin{array}{l}\text { Reading } \\
\text { Fondness }\end{array}$} & General attitude towards reading & $\begin{array}{c}1,6,9,17,18,20,25,26 \\
39,40\end{array}$ & 10 \\
\hline & Student reading preferences & $\begin{array}{c}2,4,7,12,13,15,19,22 \\
24,29,31,34,38\end{array}$ & 13 \\
\hline & $\begin{array}{l}\text { The effect of reading on students' } \\
\text { abilities }\end{array}$ & $\begin{array}{c}5,8,11,16,21,27,30,32 \\
33,36\end{array}$ & 10 \\
\hline & $\begin{array}{l}\text { Student negative views towards } \\
\text { reading * }\end{array}$ & $3,10,14,23,28,35,37$ & 7 \\
\hline & \multicolumn{2}{|l|}{ Item Total } & 40 \\
\hline
\end{tabular}

To analyze the data, researchers used the SPSS version 20 (Statistical Product and Service Solution) application to simplify the calculation of the data analysis. Data analysis techniques that researchers use are inferential statistical analysis and descriptive statistical analysis. The data that researchers have collected are then processed using the SPSS application by carrying out the Pearson correlation test and descriptive statistics to find the mean, median, minimum value, maximum value, and percentage. Correlation test is performed to determine the correlation between two variables, so there are no dependent variables and independent variables therein. In looking for correlations researchers used SPSS to find Pearson correlations.

\section{Result and Discussion}

Interest in a career in science is an indicator that shows how strong interest in students to work in science in the future. The table below shows that the more positive the answers given by students, the more interested they are in a career in science. Students' answers regarding career interests in science are shown in table 3.

Table 3. Career interests in the field of natural sciences

\begin{tabular}{|c|c|c|c|c|c|c|}
\hline \multicolumn{3}{|c|}{ Characteristics } & \multirow{2}{*}{ Mean } & \multirow{2}{*}{ Mode } & \multirow{2}{*}{ Median } & \multirow{2}{*}{$\%$} \\
\hline Interval & Scale & Total & & & & \\
\hline 10-18 & Strongly Disagree & 0 & & & & 0 \\
\hline $18.1-26$ & Disagree & 14 & & & & 9.7 \\
\hline $26.1-34$ & Neutral & 111 & 31.04 & 31 & 31 & 76.6 \\
\hline $34.1-42$ & Agree & 20 & & & & 13.8 \\
\hline $42.1-50$ & Strongly agree & 0 & & & & 0 \\
\hline & Total & 145 & & & & 100 \\
\hline
\end{tabular}


From the above data it is known that the neutral percentage holds the highest percentage of $76.6 \%$, then the second highest percentage is disagreeing at $13.8 \%$, then the third highest is disagreeing at $9.7 \%$, and the remaining $0 \%$ is strongly disagreeing, and strongly agreeing. The percentage shows that students are still hesitant to be interested in a career in the field of Natural Sciences for their future. In addition, based on statistics it is known that agreeing and strongly agreeing when added together has a combined percentage of $13.8 \%$ while strongly disagreeing and disagreeing at $9.7 \%$ this means a large percentage curve leads to agree and strongly agree and means that a small proportion of students are interested in a career in the field of Natural Sciences for the future, most are still undecided. Then based on the mean that is equal to 31.04 is in a neutral interval, then mode of 31 means in a neutral interval, then a middle value of 31 is also in a neutral interval. Mode, median, and mean data indicate that most students are still hesitant to pursue a career in the science field for their future.

Pleasure in learning science shows how strong the desire of students to be happy learning science. The table below shows that the more positive the answers given by students, the happier it is to learn science. Table 4 shows students' statements about indicators of pleasure in learning science.

Table 4. Pleasure in learning science

\begin{tabular}{ccccccc}
\hline & Characteristics & & \multirow{2}{*}{ Mean } & Mode & Median & $\%$ \\
\cline { 1 - 3 } Interval & Scale & Total & & & & 0 \\
$10-18$ & Strongly Disagree & 0 & & & \multirow{2}{*}{31} & 6.2 \\
$18.1-26$ & Disagree & 9 & & & & 76.6 \\
$26.1-34$ & Neutral & 111 & 31.3 & 34 & & 17.2 \\
$34.1-42$ & Agree & 25 & & & & $\mathbf{1 0 0}$ \\
$42.1-50$ & Strongly agree & 0 & & & & \\
\hline
\end{tabular}

From the above data it is known that the neutral percentage holds the highest percentage of $76.6 \%$, then the second highest percentage is agreeing with $17.2 \%$, then the third highest is not agreeing with $6.2 \%$, and the remaining $0 \%$ is strongly disagree, and strongly agree. The percentage shows that the attitude of students is still hesitant in fond of learning science. In addition, based on statistics it is known that agreeing and strongly agreeing when added together has a combined percentage of $17.2 \%$ while strongly disagreeing and disagreeing at $6.2 \%$ this means that a large percentage curve leads to agreeing and strongly agreeing and means some students agree that they like and like their eyes science lessons but not too great value. Then based on the mean that is equal to 31.3 is at a neutral interval, then a mode of 34 means almost in the interval between neutral and agree, then a middle value of 31 is in a neutral interval. Mode, median, and mean data indicate that some students are still somewhat hesitant to enjoy the science subjects in their schools.

The interest in increasing the time to study science shows how much students want to increase their time studying science in addition to formal activities in general in class. The table below shows the more positive student statements, the more time students spend studying science in addition to formal activities in class. Student statements about Interest in increasing the learning time of Natural Sciences are shown in table 5.

Table 5. Interest in increasing the learning time of natural sciences

\begin{tabular}{ccccccc}
\hline & Characteristics & & \multirow{2}{*}{ Mean } & \multirow{2}{*}{ Mode } & \multirow{2}{*}{ Median } & $\%$ \\
\cline { 1 - 2 } Interval & Scale & Total & & & & \\
\cline { 1 - 2 } $8.0-14.4$ & Strongly Disagree & 0 & & & & 0 \\
$14.5-20.8$ & Disagree & 4 & 25.98 & 26 & 26 & 2.8 \\
$20.9-27.2$ & Neutral & 96 & & & & 66.2
\end{tabular}




\begin{tabular}{ccccccc}
\hline & Characteristics & & \multirow{2}{*}{ Mean } & Mode & Median & $\%$ \\
\cline { 1 - 3 } Interval & Scale & Total & & & & \\
\cline { 1 - 3 } $27.3-33.6$ & Agree & 45 & & & & \\
$33.7-40$ & Strongly agree & 0 & & & \\
\hline & Total & $\mathbf{1 4 5}$ & & & $\mathbf{1 0 0}$ \\
\hline
\end{tabular}

From the above data it is known that the neutral percentage holds the highest percentage of $66.2 \%$, then the second highest percentage is not agreeing with $31 \%$, then the third highest is not agreeing with $2.8 \%$, and the remaining $0 \%$ is strongly disagree, and strongly agree. Percentage shows that students are still hesitant to increase the amount of time studied in Natural Sciences. In addition, based on statistics it is known that agreeing and strongly agreeing when added together has a combined percentage of $31 \%$ while strongly disagreeing and disagreeing at $2.8 \%$ this means a large percentage curve leads to agree and strongly agree and means that most students agree that they are interested in increasing time study science. Then based on the mean of 25.98 at a neutral interval, then a mode of 26 means that it is in a neutral interval, then a middle value of 26 is also in a neutral interval. Mode, median, and mean data indicate that some students are still a little hesitant to increase their time studying science.

The general attitude towards reading shows how the students' attitudes towards reading. The table below shows the more positive student statements, the more positive attitude toward reading. To find out the general attitudes of students towards reading, it can be seen in table 6.

Table 6. General attitudes toward reading

\begin{tabular}{|c|c|c|c|c|c|c|}
\hline \multicolumn{3}{|c|}{ Characteristics } & \multirow{2}{*}{ Mean } & \multirow{2}{*}{ Mode } & \multirow{2}{*}{ Median } & \multirow{2}{*}{$\%$} \\
\hline Interval & $\begin{array}{l}\text { Scale } \\
\end{array}$ & Total & & & & \\
\hline $10-18$ & Strongly Disagree & 0 & & & & 0 \\
\hline $18.1-26$ & Disagree & 15 & & & & 10.3 \\
\hline 26.1-34 & Neutral & 70 & 33.5 & 32 & 34 & 48.3 \\
\hline $34,1-42$ & Agree & 56 & & & & 38.6 \\
\hline $42.1-50$ & Strongly agree & 4 & & & & 2.8 \\
\hline & Total & 145 & & & & 100 \\
\hline
\end{tabular}

Based on the calculated statistical results, it was found that $48.3 \%$ of students answered neutral, $38.6 \%$ answered agreed, $10.3 \%$ answered disagreed, $2.8 \%$ answered strongly agreed, and $0 \%$ answered strongly disagreed. From the results of this percentage it can be seen that the highest percentage is held by a neutral answer that is $48.3 \%$. But the statistical results that are quite high are also held by the agreed answer which is $38.6 \%$. From the results of this percentage, it can be seen that most of the students are neutral in reading in their spare time, because the neutral percentage is inclined towards agreeing, some students also agree to read in their spare time. Based on the comparison between mode and median it is known that the mode value <median, then the most students' answers, 32, are still below the middle value of the data but are included in the neutral interval, 26.1-34. While the comparison between mean and median is known that median $>$ mean, then the average answer of students is still below the middle value of the data but is still included in the neutral interval 26.1-34. From the analyzed data it can be concluded that the attitude towards reading students is still doubtful because it is at a neutral interval.

Reading preference shows how well the type of reading source related to science that students prefer. The table below indicates that the more positive the student's statement is, the student will have a good science reading preference. To find out how much students' reading preferences are, it can be seen in table 7. 
Table 7. Student reading preferences

\begin{tabular}{|c|c|c|c|c|c|c|}
\hline \multicolumn{3}{|c|}{ Characteristics } & \multirow{2}{*}{ Mean } & \multirow{2}{*}{ Mode } & \multirow{2}{*}{ Median } & \multirow{2}{*}{$\%$} \\
\hline Interval & Scale & Total & & & & \\
\hline $13-23,4$ & Strongly Disagree & 2 & & & & 1,4 \\
\hline $23.5-33.8$ & Disagree & 6 & & & & 4,1 \\
\hline $33.9-44.2$ & Neutral & 79 & 42.7 & 39 & 43 & 54.5 \\
\hline $44.3-54,6$ & Agree & 51 & & & & 35.2 \\
\hline \multirow[t]{2}{*}{$54.7-65.0$} & Strongly agree & 7 & & & & 4,8 \\
\hline & Total & 145 & & & & 100 \\
\hline
\end{tabular}

Based on the calculated statistics, $54.5 \%$ of students answered neutral, $35.2 \%$ of students answered agree, $4.8 \%$ of students answered strongly agree, $4.1 \%$ of students answered disagree, and $1.4 \%$ of students answered strongly disagree. From these statistics it can be seen that the highest percentage is held by neutral answers at $54.5 \%$ and the second highest percentage is held by agreed answers with a percentage of $35.2 \%$. Based on these results it can be seen that most students answer neutral, and some students answer agree. However, because the neutral percentage is above $50 \%$, it can be known with certainty that students are still hesitant to make reading as a preference. Based on the comparison of mean and median data it is known that the mean is greater than the mean, but the mean results are still in the neutral interval that is 33.9-44.2. Then the comparison of mode and median data is known that the mode is smaller than the median, but the mode data is still at a neutral interval of 33.9-44.2. Overall, it can be concluded that students' reading preferences are still neutral or students are still hesitant to prioritize reading in the field of science.

The effect of reading on students 'abilities shows students' views about the effects of reading on themselves. The table below shows that the more positive the students 'statements, the better the students' views about the effects of reading on their abilities. To find out how well the effect of reading is on students' abilities, it can be seen in table 8 .

Table 8. Effects of reading on students' abilities

\begin{tabular}{ccccccc}
\hline & Characteristics & & \multirow{2}{*}{ Mean } & \multirow{2}{*}{ Mode } & \multirow{2}{*}{ Median } & $\%$ \\
\cline { 1 - 2 } Interval & Indicator & Total & & & & 0 \\
$10-18$ & Strongly Disagree & 0 & & & \multirow{2}{*}{37} & 2.8 \\
$18.1-26$ & Disagree & 4 & & & & 25.5 \\
$26.1-34$ & Neutral & 37 & 37.7 & & & 23.3 \\
$34,1-42$ & Agree & 70 & & & & $\mathbf{1 0 0}$ \\
$42.1-50$ & Strongly agree & 34 & & & & \\
\hline
\end{tabular}

Based on statistical results that have been calculated it is known that $48.3 \%$ of students answered agree, $25.5 \%$ of students answered neutral, $23.4 \%$ of students answered strongly agree, $2.8 \%$ of students answered disagree, and $0 \%$ of students answered strongly disagree. From these data it is known that the highest percentage is held by the agreed answer which is $48.3 \%$, the second highest is neutral at $25.5 \%$, and the third highest is strongly agreed at $23.4 \%$. From these results it is known that students agree and strongly agree to have a total score of $71.7 \%$, then from the data students know that it is very important the effect of reading on him. From the comparison of mode and median it is known that the mode <median, then the highest number of student choices is smaller than the middle value, but the mode is still at an agreed interval of 34.1-42. From the comparison of mean and median it is known that mean > median, the average number of answers students choose is greater than the mean value, and the mean is still at the agreed interval of 34.1-42. From the statistical results that have been analyzed it can be concluded that the students agree that reading has an effect on their abilities. 
Students' negative views of reading indicate whether according to students reading it has a negative effect on themselves. The table below shows that the more positive the students' statements are, the worse their outlook on reading is. To find out how well students view reading, it can be seen in table 9 .

Table 9. Negative views of students towards reading

\begin{tabular}{|c|c|c|c|c|c|c|}
\hline \multicolumn{3}{|c|}{ Characteristics } & \multirow{2}{*}{ Mean } & \multirow{2}{*}{ Mode } & \multirow{2}{*}{ Median } & \multirow{2}{*}{$\%$} \\
\hline Interval & Scale & Total & & & & \\
\hline $7.0-12.6$ & Strongly Disagree & 33 & & & & 22.8 \\
\hline $12,7-18,2$ & Disagree & 57 & & & & 39.3 \\
\hline 18.3-23.8 & Neutral & 40 & 16.5 & 19 & 17 & 27.6 \\
\hline $23,9-29,4$ & Agree & 15 & & & & 10.3 \\
\hline $29.5-35$ & Strongly agree & 0 & & & & 0 \\
\hline & Total & 145 & & & & 100 \\
\hline
\end{tabular}

Based on the statistical results that have been calculated, it is known that $39.3 \%$ of students answered disagree, $27.6 \%$ of students answered neutral, $22.8 \%$ of students answered strongly disagree, $10.3 \%$ of students answered agreed, and $0 \%$ of students answered strongly agree. From these data it is known that the highest percentage of disagreeing is $39.3 \%$, the second highest is neutral at $27.6 \%$, and the third highest is strongly disagreeing at $22.8 \%$. Then the percentage is known that students do not agree to have a negative view of reading. Based on the comparison of the mean and median it is known that the median > mean, but the mean interval is in disagree of 12.7-18.2. Based on the comparison of mode and median it is known that modes median, but the mode is still at the disagreeing interval of 12.7-18.2.

To find out how the correlation between reading fondness and attitudes through the data that has been collected, it is necessary to test the Pearson correlation using SPSS 20 software. The results of calculations using SPSS software are shown in table 10 below.

Table 10. Correlations of reading fondness and attitude

\begin{tabular}{cc}
\hline Pearson Correlation (r count) & Sig. \\
\hline$-0,164^{*}$ & 0,048 \\
\hline
\end{tabular}

Based on the table above it is known that the Pearson correlation value of -0.164 * Based on the comparison of the values in the $r$ table with a significance of 0.05 , the value of $r$ table $<r$ arithmetic $(0.1631<0.164)$, then, there is a weak correlation between the attitude variables with reading fondness. In addition, this weak correlation is negative, that is, an increase in attitude decreases reading habits and vice versa. Sign $\left(^{*}\right)$ means that there is a correlation between the variables associated with a significance level of $5 \%$, and there is no correlation at a significance level of $1 \%$. From the overall interpretation of the data that has been done, it can be concluded based on the Pearson correlation that there is a weak negative relationship. Based on the significance of $0.048<0.05$, there is a weak correlation between the attitude and reading variables. The results of the research that have been calculated turned out to get a correlation between reading fondness and attitude towards science is weak negative, which means that if there is an increase in the variable likes to read, then the attitude variable will experience a decrease that is not large and applies the opposite for each variable. The causes of the weak and negative influences that we get are influenced by the descriptive statistical value of each indicator of the variables. Based on Sauturrasik (2015), reading ability and reading habits have a positive correlation. Compared to the results that researchers have obtained, reading fondness and attitude are 2 different variables namely character and affective domain. So the correlation may be negative or there is no correlation. 
The interviews that researchers conducted with 2 students were as follows:

Question 1: "When you enjoy reading books or other sources of science reading, are you increasingly interested in studying science?"

Student answer 1: "Yes, I am more interested."

Student answer 2: "Yes, I am more interested."

Question 2: "Do you often come up with new ideas when reading science books?"

Student answer 1: Rarely, sometimes I get dizzier reading science books.

Student answer 2: "Yes often, my ambition to become a pharmacist by reading science books is that I am increasingly inspired."

It is known that student statements mean that attitudes toward science are linked through reading fond variables, are positive. The more fond of reading, the more happy with science, and more happy about science, the more fond of reading. Reading fondness and attitude towards science are two things that are always present in the process of learning activities in schools. Both of these variables are needed to improve the ability of students. Student attitudes toward science are classified as neutral based on indicators of career interest in the field of science, the pleasure of learning science, and interest in increasing the time of learning science, based on research (Astalini, Kurniawan, Kurniawan, \& Anggraini, 2019; Kurniawan, Astalini, Darmaji, \& Melsayanti, 2019; Maison et al., 2019), the attitude of students towards science is good. The results that researchers get are different from the results of previous studies, because students' attitudes toward science are neutral. In addition, the reading fondness variable was classified as good on the indicator of the effect of reading on students' abilities, and students' negative views on reading, while indicators of students' general attitudes towards reading, and reading preferences were still classified as neutral. The researcher concludes reading fondness is still neutral because the combined number of neutral percentages is more than any other statement. The results of Wittentirelli, Saputra, \& Putra (2019), research on reading fondness shows that the reading level of junior high school students is good. The results we get are also different from the results of previous studies which say that the reading hobby of middle school students is good.

Statistical data on indicators of attitudes towards IPA and reading fondness affect the correlation of both. The neutral results we get affect the correlation data, so it has a negative relationship. If based on interview data, someone who likes to read will like the object he is reading, in this case, is a science subject, that is, his attitude will be positive towards science. In a study at SMPN 19 Jambi City, the hobby of reading and attitude towards science was neutral so that the correlation that researchers got was weak and negative. Based on the results of the descriptive statistics we get, it also indicates that teachers pay less attention to attitudes towards science and students' fondness for reading. Correlation data that shows a negative relationship should be positive if attitudes toward science and reading fondness are considered and improved.

\section{Conclusions and Suggestions}

Reading fondness and attitude towards science are very much needed in learning activities in the science class. Based on statistical results on attitudes indicators obtained, students choose neutral indicators of career interest in the field of science, students choose neutral indicators of enjoyment in learning science, students choose neutral indicators of interest to increase the learning time of science. While the reading fondness variable in terms of indicators, students choose neutral on indicators of general attitudes towards reading, students choose neutral on indicators of reading preferences, students choose to agree on indicators of the effects of reading on ability and students choose not to agree with negative views of students reading. The correlation obtained between reading fondness variables and attitudes toward science is weak and negative. Future researchers are expected to develop this research, especially in the field of attitudes toward science and reading fondness. This research certainly has a limited scope on interesting objects in reading and attitude, so that suggestions for future researchers to develop from the literacy, cognitive, and psychomotor aspects to complete the limitations of this study. 


\section{References}

Ahmed, S. 2016. Reading habits and attitudes of UMSKAL undergraduates. International Journal of Applied Linguistics and English Literature, 5(2): 189-201. https://doi.org/10.7575/aiac.ijalel.v.5n.2p.189.

Asrial, A., Syahrial, S., Kurniawan, D. A., \& Septiasari, R. 2019. Relationship of Pedagogical Competence and Science Competency of Elementary School Teacher Education. Pedagogia: $\quad J u r n a l \quad$ Pendidikan, $8(2)$ 149-157. https://doi.org/0.21070/pedagogia.v8i2.1872.

Astalini, A., \& Kurniawan, D. A. 2019. Pengembangan Instrumen Sikap Siswa Sekolah Menengah Pertama Terhadap Mata Pelajaran IPA. Jurnal Pendidikan Sains (Jps), 7(1): 1-7. https://doi.org/10.26714/jps.7.1.2019.1-7.

Astalini, A., Kurniawan, D. A., Melsayanti, R., \& Destianti, A. 2018. Sikap Terhadap Mata Pelajaran Ipa Di Smp Se-Kabupaten Muaro Jambi. Lentera Pendidikan: Jurnal IImu Tarbiyah Dan Keguruan, 21(2): 214-227. https://doi.org/10.24252/lp.2018v21n2i7.

Astalini, A., Kurniawan, D. A., \& Sumaryanti, S. 2018. Sikap Siswa Terhadap Pelajaran Fisika di SMAN Kabupaten Batanghari. JIPF (Jurnal IImu Pendidikan Fisika), 3(2): 59-64. https://doi.org/10.26737/jipf.v3i2.694.

Astalini, Kurniawan, D. A., Kurniawan, N., \& Anggraini, L. 2019. Evaluation of Student's Attitude Toward Science in Indonesia. Open Journal for Educational Research, 3(1): 1-12. https://doi.org/10.32591/coas.ojer.0302.01039h.

Astalini, Maison, Ikhlas, M., \& Kurniawan, D. A. 2018. Pengembangan Instrumen Sikap Mahasiswa Terhadap Mata Kuliah Fisika Matematika. Edusains, 10(1): 46-52. https://repository.unja.ac.id/id/eprint/3417.

Creswell, J. W., \& Creswell, J. D. 2018. Qualitative, Quantitative, and Mixed Methods Research Designs (5th ed.). California: SAGE Publication Inc. https://doi.org/10.1891/9780826146373.0007.

Dewi, R., Budiarti, R. S., \& Aina, M. 2017. The Development Of Learner Activity Sheet- Carged Character Education With A Learning Model Of Guided Inquiry On Material Of Bacteria For Students Of Class X High School. Biodik, 3(1): 17-26. https://doi.org/10.22437/bio.v3i1.4878.

Dwianto, A., Wilujeng, I., Prasetyo, Z. K., \& Suryadarma, I. G. P. 2017. The development of science domain based learning tool which is integrated with local wisdom to improve science process skill and scientific attitude. Jurnal Pendidikan IPA Indonesia, 6(1): 2331. https://doi.org/10.15294/jpii.v6i1.7205.

Ernawati, M. D. W., Muhammad, D., Asrial, A., \& Muhaimin, M. 2019a. Development of Creative Thinking Skill Instruments for Chemistry Student Teachers in Indonesia. International Journal of Online and Biomedical Engineering (IJOE), 15(14): 21-30. https://doi.org/10.3991/ijoe.v15i14.11354.

Ernawati, M. D. W., Muhammad, D., Asrial, A., \& Muhaimin, M. 2019b. Identifying creative thinking skills in subject matter bio-chemistry. International Journal of Evaluation and Research in Education (IJERE), 8(4): 581-589. https://doi.org/10.11591/ijere.v8i4.20257.

Fatimah, N. E., \& Usman, N. 2017. Implementasi Pendidikan Karakter Dalampembelajaran Fiqih Di Mi Al Islam Tonoboyo Kecamatan Bandongan Kabupaten Magelang. Tarbiyatuna, $8(1)$ :

9-22. http://journal.ummgl.ac.id/index.php/tarbiyatuna/article/view/1750.

Kurniawan, D. A., Astalini, A., Darmaji, D., \& Melsayanti, R. 2019. Students' attitude towards natural sciences. International Journal of Evaluation and Research in Education, 8(3): 455-460. https://doi.org/10.11591/ijere.v8i3.16395.

Kurniawan, D. A., Astalini, \& Anggraini, L. 2018. Evaluasi Sikap Siswa Smp Terhadap Ipa Di Kabupaten Muaro Jambi. Ilmiah Didaktika, 19(1): 124-139. http://dx.doi.org/10.22373/jid.v19i1.4198. 
Liswaniso, B. L., \& Mubanga, G. N. 2019. Examining the reading habits of university students: A study of students at the katima mulilo campus of the university of namibia. Electronic Journal of Foreign Language Teaching, 16(1): 140-152. https://e-flt.nus.edu.sg/wpcontent/uploads/2021/03/liwaniso.pdf.

Maison, Ernawati, M. D. W., Budiarti, R. S., Kurniawan, W., Ningsih, Y., Puspitasari, T. O., ... Putra, D. S. 2019. Learning in nature science: social implications, normality of scientist, attitudes towards investigation of natural science, and interest adds to science learning time. International Journal of Scientific and Technology Research, 8(12): 1478-1484. https://repository.unja.ac.id/id/eprint/12969.

Mayasari, H., Syamsurizal, \& Maison. 2015. Pengembangan Lembar Kerja Siswa (LKS) Berbasis Karakter melalui Pendekatan Saintifik pada Materi Fluida Statik untuk Sekolah Menengah Atas. Edu-Sains, 4(2): 30-36. https://doi.org/10.22437/jmpmipa.v4i2.2533.

Nurchaili. 2016. Menumbuhkan Budaya Literasi Melalui Buku Digital. LIBRIA, 8(2): 197-209. https://jurnal.ar-raniry.ac.id/index.php/libria/article/view/1211.

Piawi, K., Kalmar Nizar, U., \& Mawardi, M. 2018. Development of student worksheet based on guided inquiry with class activity and laboratory in thermochemistry material. Unnes Science Education Journal, 7(1): 679-683. https://doi.org/10.29210/20181100.

Ruel, E., III, W. E. W., \& Gillespie, B. J. 2016. The Practice of Survey Research Theory and Applications. California: SAGE Inc. https://doi.org/10.4324/9781351054621-2.

Rumahlatu, D., Huliselan, E. K., \& Takaria, J. 2016. An analysis of the readiness and implementation of 2013 curriculum in the west part of Seram District, Maluku Province, Indonesia. International Journal of Environmental and Science Education, 11(12): 5662-5675. https://eric.ed.gov/?id=EJ1115675.

Salim, \& Haidir. 2019. Penelitian Pendidikan Metode, Pendekatan, dan Jenis. Kencana.

Sauturrasik. 2015. Kemampuan Membaca Pemahaman Siswa Kelas Xi Ipa Sman 1 Ambunten. Jurnal Lentera Sains (Lensa), 5(1): 25-34. https://doi.org/10.24929/lensa.v5i1.243.

Silaban, S. 2017. Dasar-Dasar Pendidikan Matematika dan IImu Pengetahuan Alam. Harapan Cerdas Publisher.

Siyoto, S., \& Sodik, M. A. 2015. Dasar Metodologi Penelitian. Literasi Media Publishing.

Supriyadi, \& Kholid, M. R. 2016. Analisis Kritis Dampak Internet Terhadap Perilaku Membaca Mahasiswa. Bioedukasi Jurnal Pendidikan Biologi, 10(1): 82-100. http://dx.doi.org/10.24127/bioedukasi.v10i1.2013.

Syafitri, R., Asyhar, R., \& Asrial. 2016. Pengaruh Model Inquiry Training dan Berpikir Kritis Terhadap Kemampuan Berpikir Ilmiah Mahasiswa pada Mata Kuliah Kimia Dasar. EduSains, 5(1): 1-9. https://doi.org/10.22437/jmpmipa.v5i1.2849.

Syahrial, S., Asrial, A., Kurniawan, D. A., Nugroho, P., Septiasari, R., Pratama, R. A., \& Perdana, R. 2019. Increased Behavior of Students' Attitudes to Cultural Values Using the Inquiry Learning Model Assisted by Ethnoconstructivism. Journal of Educational Science and Technology (EST), 5(2): 166-175. https://doi.org/10.26858/est.v5i2.9670.

Webber, J. 2015. Character, attitude and disposition. European Journal of Philosophy, 23(4): 1082-1096. https://doi.org/10.1111/ejop.12028.

Wittentirelli, Saputra, A. H., \& Putra, A. E. 2019. Analisis Karakter Gemar Membaca Siswa Smp Negeri 30 Muaro Jambi. Briliant: Jurnal Riset Dan Konseptual, 4(2): 182-188. http://dx.doi.org/10.28926/briliant.v4i2.305. 